\title{
Theoretical Study of Trioxane Derivatives as Amphi-ionophores: Importance of Charge-Dipolar Moiety Orientation
}

\author{
Seung Joo Cho \\ Department of Cellular-Molecular Medicine, School of Medicine, Chosun University, Korea.E-mail: chosj@chosun.ac.kr \\ Received May 1, 2014, Accepted May 15, 2014
}

\begin{abstract}
Recently we have reported a novel class of anion receptors which are based on 2n-crown-n topology. Trioxane derivatives are capable of anion sensing through pure aliphatic $\mathrm{C}-\mathrm{H}$ hydrogen bonding. In this work, we highlight another interesting property, i.e., they can also recognize cations as normal crown ethers ( 3 n-crown$\mathrm{n}$ topology). Since the same functional moiety can recognize anions and cations, these coronands are predicted to be amphi-ionophores. However, we could not detect cations even in the gas phase. Considering trioxane is analogous to $\left[1_{6}\right]$ starand, this was rather counter-intuitive. The calculation results show that these coronands can detect alkali metals with very low affinity. The low affinity toward cations should be responsible for this failure of experimental detection. With careful theoretical study, we found that this low affinity toward cations could be explained by the unfavorable charge-dipolar moiety orientations as proposed by Cui et al. As in the case of [ $\left.1_{6}\right]$ starand, this is an example that underscores the importance of charge-dipolar moiety orientation in supramolecular interactions.
\end{abstract}

Key Words : Trioxane, Crown ether, Amphi-ionophore, Charge-dipole, 2n-crown-n

\section{Introduction}

Most crown ethers have the repeating unit of -OCC- which results in 3n-crown-n topology. Since there are very few examples, it has been implicitly assumed that -OC- repeating units would not be stable. In 1993, new crown ethers with 2ncrown-n topology were reported. ${ }^{1}$ These hosts have desirable characteristics such as high oxygen content, rigidity, and sphericity for higher affinity and selectivity toward cations (Figure 1(a)). Inspired by the unusual topology of [ $\left.1_{n}\right]$ starands, which possess 2 n-crown-n moiety at the center, we tried to remove the external benzene ring moieties from them. It was assumed implicitly that outer benzene rings could be important for stabilization of $\left[1_{n}\right]$ starands. However, our computational results indicate the central structures without external benzene groups could also be stable. Recently we have reported a novel class of anion receptors which are composed of crown ether moiety (Figure 1(b)). ${ }^{2}$ The topology (2n-crown-n) is different from normal crown ethers those are based on $3 n-$ crown-n topology. As a result, we managed to obtain a new class of stable $2 n$-crown-n ethers where $n=3$, as shown in Figure 1.

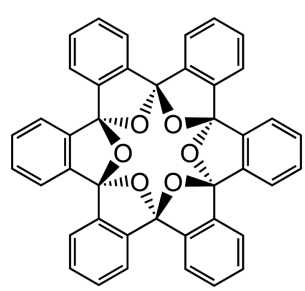

(a)

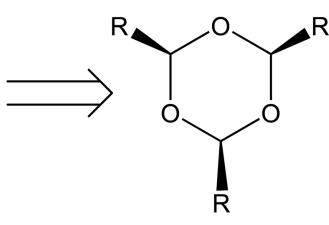

(b)
Figure 1. $\left[1_{6}\right]$ starand (a) and 6-crown-3 ether (b), both with 2 ncrown- $n$ topology, where $n=6(a)$ and $n=3(b)$, respectively.
Unlike usual crown ethers with 3n-crown-n topology, these coronands can recognize anions through positively polarized $\mathrm{C}-\mathrm{H}$ groups. In addition, like usual crown ethers, trioxane derivatives should sense cations through three oxygen atoms. Actually, there are examples of cation sensing with these scaffold. ${ }^{3}$ Starands were found to be a stronger cation sensing hosts compared with corresponding crown ethers. For example, $\left[1_{8}\right]$ starand has the affinity higher than that of 12-crown-4 toward $\mathrm{Na}^{+}$in methanol. ${ }^{4}$ Since both trioxane and $\left[1_{\mathrm{n}}\right]$ starands share same topology of $2 n$-crown-n moiety, trioxane derivatives should be capable of sensing cations. It should be interesting to investigate the affinity and selectivity of these newly found hosts toward alkali metal ions. Although we have tried to detect cation sensing both in solution (NMR) and in gas phase (MS), we could not identify them. In this work, we investigated the binding behaviors of trioxane derivatives toward cations through the computational work using density functional theory (DFT). For trioxane based hosts we studied five derivatives as shown in Figure 1(b) with the two smallest alkali metal guests $\left(\mathrm{Li}^{+}\right.$and $\left.\mathrm{Na}^{+}\right)$to study the affinity and selectivity issues. To investigate the intrinsic molecular recognition property, the computational study was focused the interactions in the gas phase to avoid complicated solvation effects.

\section{Computational Methods}

All the computations were performed with Gaussian09 Suite of programs. ${ }^{5}$ B3LYP functional ${ }^{6}$ and standard basis set of $6-31++\mathrm{G}^{* *}$ was used for all atoms. All geometries were fully optimized and confirmed to be at the local minima via frequency calculations except monoatomic cations $\left(\mathrm{Li}^{+}\right.$and $\mathrm{Na}^{+}$). Basis set superposition energy was corrected ${ }^{7}$ and Gibbs free energy was calculated based on the harmonic potential 
approximation. For hosts 3, and 4, we found several other conformers which are resulted from C-C single bond rotations. We only report the most stables conformers for 5 hosts (free and alkali metal complexed states).

Partial charges were obtained from natural population analysis (NPA) using NBO (version 3$)^{8}$ and atoms in molecules (AIM) theory. ${ }^{9}$ AIM analysis was performed with AIMALL program. $^{10}$

\section{Results}

In Table 1 , the binding energies $(\Delta \mathrm{E})$ and basis set superposition energy corrected binding energies $\left(\Delta \mathrm{E}_{\mathrm{BSSEC}}\right)$ are reported. The binding energy for each $\mathrm{Li}^{+}$complex was consistently more stable than the corresponding $\mathrm{Na}^{+}$complex by about $11-14 \mathrm{kcal} / \mathrm{mol}$. This should be from more affinity of $\mathrm{Li}^{+}$toward oxygen atoms. The effect of basis set superposition error correction (BSSEC) was $0.7-0.9 \mathrm{kcal} / \mathrm{mol}$ for $\mathrm{Li}^{+}$, while 1.1-1.6 for $\mathrm{Na}^{+}$. The bigger BSSEC for $\mathrm{Na}^{+}$may be attributed to the more diffuse orbital of $\mathrm{Na}^{+}$. BSSEC did not change overall trend of relative binding energy. The thermal correction after Hessian calculations $\left(\Delta \mathrm{G}_{\text {therm }}\right)$, gave a little less binding energies by about $1-2 \mathrm{kcal} / \mathrm{mol}$. Since the trend does not change and the energy differences are rather small, the argument afterwards will be based on the $\Delta \mathrm{G}_{\text {therm }}$. Among five hosts, host 3 shows the highest binding affinity against alkali metal ions. When host $\mathbf{3}$ is compared with host $\mathbf{1}$ and $\mathbf{2}$, the reason for the larger affinity is obvious from the complexation pose as shown in Figure 3. In addition to 3 oxygen atoms, 3 chlorine atoms are close to the $\mathrm{Li}^{+}$, this should increase the

Table 1. Binding energies between trioxane derivatives and cations in gas phase (B3LYP/6-31++G**) ${ }^{a}$

\begin{tabular}{cccccccc}
\hline \multirow{2}{*}{ Host } & \multicolumn{3}{c}{$\mathrm{Li}^{+} \cdot$ host } & & \multicolumn{3}{c}{$\mathrm{Na}^{+} \cdot$ host } \\
\cline { 2 - 3 } \cline { 6 - 8 } & $\Delta \mathrm{E}$ & $\Delta \mathrm{E}_{\text {BSSEC }}$ & $\Delta \mathrm{G}_{\text {therm }}$ & & $\Delta \mathrm{E}$ & $\Delta \mathrm{E}_{\text {BSSEC }}$ & $\Delta \mathrm{G}_{\text {therm }}$ \\
\hline $\mathbf{1}$ & -42.76 & -42.05 & -41.30 & & -31.44 & -30.36 & -31.09 \\
$\mathbf{2}$ & -50.45 & -49.64 & -48.68 & & -36.65 & -35.28 & -36.02 \\
$\mathbf{3}$ & -66.64 & -65.89 & -64.58 & & -53.08 & -51.63 & -51.30 \\
$\mathbf{4}$ & -54.28 & -53.38 & -52.51 & & -40.79 & -39.18 & -39.39 \\
$\mathbf{5}$ & -48.87 & -48.01 & -47.18 & & -35.25 & -33.63 & -33.89 \\
\hline
\end{tabular}

${ }^{a} \Delta \mathrm{E}_{\mathrm{BSSEC}}$, binding energy after basis set superposition error correction. $\Delta \mathrm{G}_{\text {therm }}$, Gibbs binding free energy followed by frequency calculation. Units are in $\mathrm{kcal} / \mathrm{mol}$. See Figure 1 for host structures.

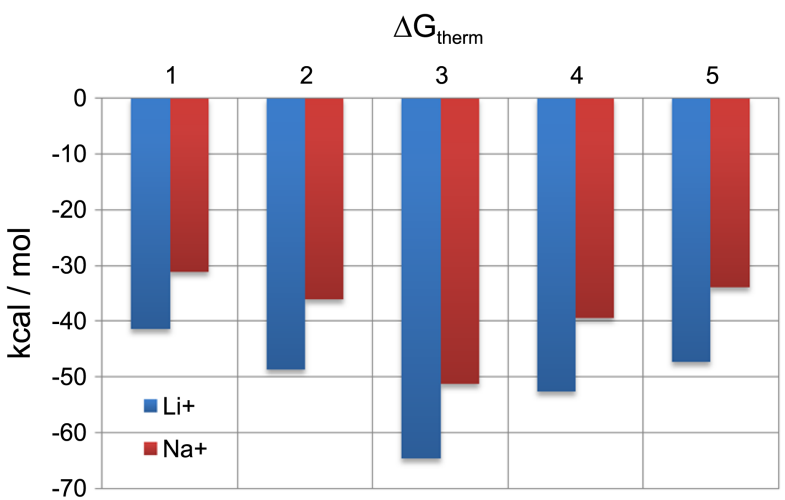

Figure 2. Gibbs binding free energies of trioxane based hosts (1, 2, $\mathbf{3}, \mathbf{4}$, and $\mathbf{5}$ ) against lithium and sodium ions.

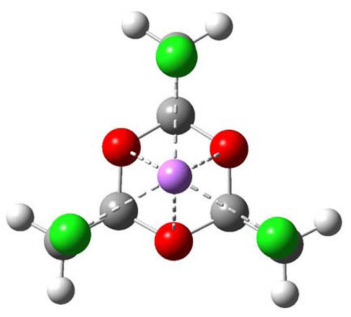

(a) Top View

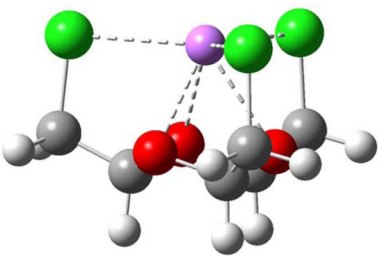

(b) Side View
Figure 3. The binding pose of host $\mathbf{3}$ and $\mathrm{Li}^{+}$. (a) Top view. (b) Side view.

affinity between $\mathrm{Li}^{+}$and host 3 . The coordination was also confirmed with AIMALL program. Then, why would host 4 and $\mathbf{5}$ have less binding energies? AIM analysis shows that there are some covalent characterics for $\mathrm{Cl} \cdots \mathrm{M}^{+}$interactions in addition to $\mathrm{Cl} \cdots \mathrm{M}^{+}$interactions. However, with more chlorine atom substitutions, the partial charge of methyl carbon becomes more positive, and this induces lower affinities due to electrostatic repulsion between two positively polarized atoms $\left(\mathrm{C} \cdots \mathrm{M}^{+}\right)$. It is calculated that host $\mathbf{3}$ has the strongest binding affinity compared with other hosts.

\section{Discussion}

Since trioxane derivatives are a new class of crown ethers, it should be interesting to compare the binding affinity and selectivity toward alkali metal ions with other ethereal hosts. Previous computational binding energy $\left(\Delta \mathrm{E}_{\mathrm{BSSEC}}\right)$ for a model

Table 2. Geometries and charges between trioxane derivatives and cations

\begin{tabular}{|c|c|c|c|c|c|c|c|c|c|c|c|c|}
\hline \multirow{3}{*}{ Host } & \multicolumn{6}{|c|}{$\mathrm{Li}^{+}$} & \multicolumn{6}{|c|}{$\mathrm{Na}^{+}$} \\
\hline & \multicolumn{2}{|c|}{ NPA } & \multicolumn{2}{|c|}{ AIM } & \multirow{2}{*}{$\mathrm{d}\left(\mathrm{Li}^{+}-\mathrm{O}\right)$} & \multirow{2}{*}{$\alpha$} & \multicolumn{2}{|c|}{ NPA } & \multicolumn{2}{|c|}{ AIM } & \multirow{2}{*}{$\mathrm{d}\left(\mathrm{Na}^{+}-\mathrm{O}\right)$} & \multirow{2}{*}{$\alpha$} \\
\hline & $\mathrm{q}\left(\mathrm{Li}^{+}\right)$ & $q(O)$ & $\mathrm{q}\left(\mathrm{Li}^{+}\right)$ & $q(O)$ & & & $\mathrm{q}\left(\mathrm{Na}^{+}\right)$ & $q(O)$ & $\mathrm{q}\left(\mathrm{Li}^{+}\right)$ & $q(O)$ & & \\
\hline 1 & 0.886 & -0.621 & 0.947 & -1.081 & 2.1098 & 91.34 & 0.936 & -0.624 & 0.948 & -1.076 & 2.4677 & 86.24 \\
\hline 2 & 0.841 & -0.639 & 0.935 & -1.083 & 2.0586 & 91.94 & 0.903 & -0.637 & 0.936 & -1.078 & 2.4332 & 86.35 \\
\hline 3 & 0.558 & -0.598 & 0.920 & -1.093 & 2.3414 & 90.73 & 0.726 & -0.604 & 0.908 & -1.082 & 2.6324 & 85.84 \\
\hline 4 & 0.559 & -0.594 & 0.919 & -1.094 & 2.3319 & 90.07 & 0.732 & -0.596 & 0.910 & -1.081 & 2.6390 & 84.96 \\
\hline 5 & 0.564 & -0.591 & 0.919 & -1.094 & 2.3117 & 89.55 & 0.741 & -0.592 & 0.911 & -1.080 & 2.6300 & 84.27 \\
\hline
\end{tabular}

${ }^{a} \Delta \mathrm{E}_{\mathrm{BSSEC}}$, binding energy after basis set superposition error correction. $\Delta \mathrm{G}_{\mathrm{therm}}$, Gibbs binding free energy followed by frequency calculation. Units are in $\mathrm{kcal} / \mathrm{mol}$. See Figure 1 for host structures. 


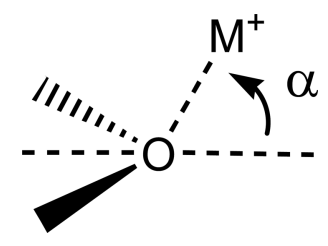

Figure 4. Definition of a to quantify charge-dipolar moiety orientation.

[16] starand with $\mathrm{Li}^{+}$was $-90.4 \mathrm{kcal} / \mathrm{mol}$ at the Hartree-Fock level $\left(6-31+\mathrm{G}^{*}\right)$. While with 12-crown-4, the binding energy $\left(\triangle \mathrm{E}_{\mathrm{BSSEC}}\right)$ was calculated $-88.8 \mathrm{kcal} / \mathrm{mol}$. At the MP2 level calculation using HF optimized geometry the value was quite similar $(-86.8 \mathrm{kcal} / \mathrm{mol}){ }^{3 \mathrm{c}} \Delta \mathrm{E}_{\mathrm{BSSEC}}$ value between the trioxane (host 1 ) and $\mathrm{Li}^{+}$is only $-42.1 \mathrm{kcal} / \mathrm{mol}$. Compared with other representative ethereal hosts above ([16]starand and 12-crown4), the affinity of trioxane (host $\mathbf{1}$ ) for $\mathrm{Li}^{+}$is surprisingly low. Cui et al. argued that the relative orientation of metal and ethereal moieties were crucial for binding affinity. This is attributed to the electronic nature of ion recognition. The charge-dipolar moiety orientation could be quantified by the out-of-plane bending angle of a metal ion from the C-O-C plane. This is defined as the angle a as shown in Figure 4. They showed that if a) become close to 90, the relative energy againt the most favorable orientation $(=0)$ is about $20 \mathrm{kcal} /$ mol per charge-dipole. For trioxane case, since there are three charge-dipole interactions for trioxane-lithium complex, this would be responsible for large destabilization ( $\sim 60 \mathrm{kcal} /$ $\mathrm{mol}$ ). Therefore the unfavorable charge-dipolar moiety orientation seems to be one of the most important factors for this low affinity of trioxane (host $\mathbf{1}$ and other derivatives). Since trioxane derivatives are a special type of crown ether, they can recognize cations like normal crown ethers. Since both cation and anions can be sensed with the same functional moiety, these hosts can be classified as amphi-ionophores. ${ }^{11}$

\section{Conclusions}

In addition to anion recognition, trioxane derivatives can also recognize cations like conventional crown ethers. Since the same functional moiety can recognize anions and cations, these coronands are amphi-ionophores. However, the calculation results indicate that these coronands can recognize cations only with very low affinity. This should come from the unfavorable charge-dipolar moiety orientations as proposed by Cui et al. As in the case of [16]starand, this is an example that underscores the importance of charge-dipolar moiety orientation in supramolecular interactions.
Acknowledgments. This study was supported by research funds from Chosun University 2014.

\section{References}

1. (a) Lee, W. Y.; Park, C. H. The Journal of Organic Chemistry 1993, 58(25), 7149-7157. (b) Lee, W. Y.; Park, C. H.; Kim, H.-J.; Kim, S. The Journal of Organic Chemistry 1994, 59(4), 878-884. (c) Lee, W. Y.; Park, C. H.; Kim, Y. D. The Journal of Organic Chemistry 1992, 57(15), 4074-4079.

2. Shi, G.; Gadhe, C. G.; Park, S. W.; Kim, K. S.; Kang, J.; Seema, H.; Singh, N. J.; Cho, S. J. Org. Lett. 2014, 16(2), 334-7.

3. (a) Cho, S. J. Journal of Molecular Structure: THEOCHEM 2000, 499(1-3), 111-119. (b) Cho, S. J.; Kollman, P. A. The Journal of Organic Chemistry 1999, 64(16), 5787-5793. (c) Cui, C.; Cho, S. J.; Kim, K. S. The Journal of Physical Chemistry A 1998, 102(7), 1119-1123. (d) Cho, S. J.; Hwang, H. S.; Park, J. M.; Oh, K. S.; Kim, K. S. J. Am. Chem. Soc. 1996, 118(2), 485-486.

4. Hwang, S.; Lee, K. H.; Ryu, G. H.; Jang, Y. H.; Lee, S. B.; Lee, W. Y.; Hong, J.-I.; Chung, D. S. The Journal of Organic Chemistry 1999, 65(2), 536-542.

5. Frisch, M. J. T., G. W.; Schlegel, H. B.; Scuseria, G. E.; Robb, M. A.; Cheeseman, J. R.; Scalmani, G.; Barone, V.; Mennucci, B.; Petersson, G. A.; Nakatsuji, H.; Caricato, M.; Li, X.; Hratchian, H. P.; Izmaylov, A. F.; Bloino, J.; Zheng, G.; Sonnenberg, J. L.; Hada, M.; Ehara, M.; Toyota, K.; Fukuda, R.; Hasegawa, J.; Ishida, M.; Nakajima, T.; Honda, Y.; Kitao, O.; Nakai, H.; Vreven, T.; Montgomery, J. A., Jr.; Peralta, J. E.; Ogliaro, F.; Bearpark, M.; Heyd, J. J.; Brothers, E.; Kudin, K. N.; Staroverov, V. N.; Kobayashi, R.; Normand, J.; Raghavachari, K.; Rendell, A.; Burant, J. C.; Iyengar, S. S.; Tomasi, J.; Cossi, M.; Rega, N.; Millam, N. J.; Klene, M.; Knox, J. E.; Cross, J. B.; Bakken, V.; Adamo, C.; Jaramillo, J.; Gomperts, R.; Stratmann, R. E.; Yazyev, O.; Austin, A. J.; Cammi, R.; Pomelli, C.; Ochterski, J. W.; Martin, R. L.; Morokuma, K.; Zakrzewski, V. G.; Voth, G. A.; Salvador, P.; Dannenberg, J. J.; Dapprich, S.; Daniels, A. D.; Farkas, Ö.; Foresman, J. B.; Ortiz, J. V.; Cioslowski, J.; Fox, D. J. Gaussian 09, Revision D.01; Gaussian Inc.: 2009.

6. Becke, A. D. The Journal of Chemical Physics 1993, 98, 56485652 .

7. Boys, S. F. Rev. Mod. Phys. 1960, 32, 296-299.

8. (a) Foster, J. P.; Weinhold, F. J. Am. Chem. Soc. 1980, 102(24), 7211-7218. (b) Reed, A. E.; Curtiss, L. A.; Weinhold, F. Chemical Reviews 1988, 88(6), 899-926. (c) Reed, A. E.; Weinstock, R. B.; Weinhold, F. The Journal of Chemical Physics 1985, 83(2), 735746.

9. Boyd, C. F. M. R. J. The Quantum Theory of Atoms in Molecules; WILEY-VCH: 2007.

10. Gristmill, T. A. K. T. AIMAll (Version 14.04.17), Todd A. Keith, TK Gristmill Software; aim.tkgristmill.com: 2014.

11. (a) Suh, S. B.; Cui, C.; Son, H. S.; U, J. S.; Won, Y.; Kim, K. S. The Journal of Physical Chemistry B 2002, 106(8), 2061-2064. (b) Kim, K. S.; Cui, C.; Cho, S. J. The Journal of Physical Chemistry B 1998, 102(2), 461-463. 